УДК [597.556.31-11:574.632](262.5)

\title{
СОСТОЯНИЕ БИОМОНИТОРНОГО ВИДА ЧЕРНОМОРСКОЙ СКОРПЕНЫ (SCORPAENA PORCUS LINNAEUS, 1758) В ПРИБРЕЖНЫХ АКВАТОРИЯХ СЕВАСТОПОЛЯ*
}

\author{
Кузьминова Н. С. ${ }^{1,2}$, Зозуль А. Ю. ${ }^{2}$, Гребнев В. И. ${ }^{3}$, Васильева А. А. ${ }^{3}$, Цыгылык Е. И. ${ }^{3}$
}

${ }^{1}$ ФГБУН ФИЦ «Институт биологии южных морей имени А. О. Ковалевского РАН», г. Севастополь, Российская Федерация,

${ }^{2}$ ГБОУ ДО «Севастопольский центр эколого-натуралистического творчества учащейся молодёжи», 2. Севастополь, Российская Федерация,

${ }^{3}$ Севастопольский государственный университет, г. Севастополь, Российская Федерация, e-mail:kunast@rambler.ru

В работе представлены данные по размерно-массовым, морфофизиологическим характеристикам черноморского ерша из пяти бухт г. Севастополя в период 2017-2019 гг. Установлено, что молодые экземпляры крупнее в бухтах Карантинной (TL 13,5 \pm 0,19 см) и Севастопольской (TL 14,2 \pm 0,23 cм), а особи среднего возрастного класса — в Балаклавской (TL 15,9 \pm 0,35 cм), Круглой (TL 16,9 $\pm 2,45$ см) и Стрелецкой (TL 16,06 \pm 0,5 cм). В ответ на бо́льший уровень комплексного загрязнения Стрелецкой бухты у самцов разного возраста индекс печени (ИП) повышен. Такой же адаптивный эффект - индекс жабр имеет максимальные значения — отмечен для особей из бухт Круглая и Стрелецкая. У самок скорпены из Балаклавской бухты в возрасте от трёх до восьми лет увеличен ИП, это является следствием более калорийного рациона (преобладание рыб), что подтверждается как анализом пищевого спектра ерша, так и величинами некоторых биохимических параметров жирового обмена (уровень холестерина, $\beta$-липопротеидов и липазы). Итак, в 2017-2019 гг. ёрш находился в более благоприятном физиологическом состоянии в бухтах Балаклавской и Карантинной и в менее благоприятном — в акватории бухты Стрелецкой.

Ключевые слова: морской ёрш, бухты Севастополя, загрязнение.

\section{Введение}

Параметры различного уровня представителей донной ихтиофауны, в том числе черноморской, являются наиболее информативными при характеристике условий обитания рыб [Овен, Руднева, Шевченко, 2000]. Ранее были описаны отклики черноморской скорпены, бычкакругляка и трёхусого налима на различные уровни загрязнения севастопольских бухт в период исследований, проведённых с 1998 г. по настоящее время [Овен, Руднева, Шевченко, 2000; Руднева, 2000; Экотоксикологические..., 2016].

В связи с тем что в последнее десятилетие по ряду ихтиологических параметров, а также по другим показателям среды и гидробионтов можно констатировать некоторое улучшение состояния прибрежных акваторий Севастополя или даже отдельных участков болыших бухт [Вдодович, 2008; Климова, 2010; Котельянец и др., 2019; Ревков, 2011; Санитарно-биологические исследования..., 2018; Экотоксикологические..., 2016], работы по биоиндикации с использованием рыб продолжают оставаться актуальными.

Целью настоящих исследований является определение и анализ биологических параметров черноморского ерша Scorpaena porcus Linnaeus, 1758, отловленного в пяти бухтах г. Севастополя.

\footnotetext{
* Работа выполнена в рамках госзадания № 075-00744-21-00 «Молисмологические и биогеохимические основы гомеостаза морских экосистем».
} 


\section{Материалы и методы}

Оценку состояния черноморской скорпены проводили на особях, отловленных в бухтах г. Севастополя: Карантинной, Круглой, Большой Севастопольской (орудия лова использовали только в бухтах Александровской и Матюшенко, входящих в её состав), Балаклавской, Стрелецкой (рис. 1). В течение 2017-2019 гг. биоанализ рыб включал определение размеров, массы, пола особей по методам, описанным ранее [Правдин, 1966]. В качестве морфофизиологических параметров рассчитывали индекс печени (ИП) и индекс жабр (ИЖ) согласно методу [Шварц, Смирнов, Добринский, 1968] в пересчёте на массу тушки. Возраст рыб определяли по отолитам при 16-тикратном увеличении на микроскопе «Микромед МС-1 вар. 1В».

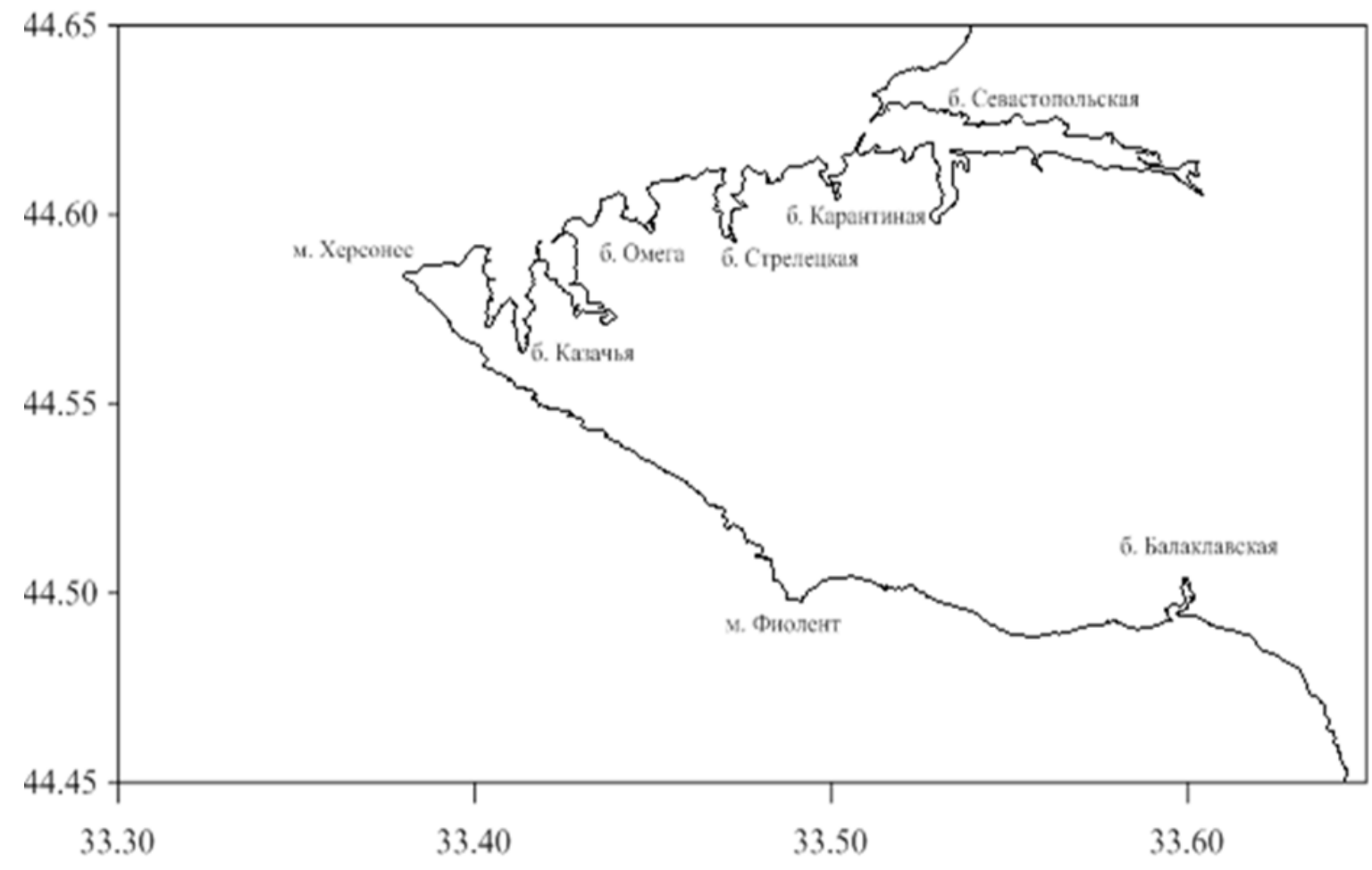

Рис. 1. Районы отлова рыб в прибрежной акватории г. Севастополя

В работе были использованы ранее (2015 г.) проведённые биохимические исследования печени для объяснения полученных результатов биологического и морфофизиологического анализов скорпены. Концентрацию общего холестерина определяли с помощью стандартного набора реактивов ООО «Ольвекс Диагностикум», концентрацию $\beta$-липопротеидов - согласно методам [Цитофізіологія..., 2006], активность липазы - с помощью модифицированного метода [Кучеренко, Васильев, 1985; Методические указания..., 2011]. Концентрацию холестерина и липазы пересчитывали на 1 г белка. Концентрацию общего белка определяли в гомогенате печени с помощью стандартного набора реактивов фирмы «Филисит».

Результаты всех измерений обрабатывали статистически с помощью стандартной программы Microsoft Excel. Сравнительный анализ популяционных, морфофизиологических и биохимических показателей особей из разных акваторий осуществляли с помощью t-критерия Стьюдента, а также критерия Манна - Уитни в зависимости от объёма выборки [Пример расчета t-критерия Стьюдента...; Пример расчета критерия U Манна — Уитни]. 


\section{Результаты и обсуждение}

Установлено, что для возрастной группы два - три года наибольшие показатели размера и массы скорпены отмечены в бухтах Карантинной и Севастопольской (табл. 1). В возрасте четырёх — пяти лет как самки, так и самцы были крупнее в Балаклавской, Круглой и Стрелецкой бухтах.

Ранее сходные различия по размеру и массе рыб из бухты Балаклавской и удалённого от неё участка прибрежной акватории (от бухты Карантинной до начала Севастопольской) были отмечены и для ставриды [Кузьминова, Мурзин, Самотой, 2018]: в первой акватории ставрида имеет более высокие величины размера, массы, высоты тела, а также гонадосоматического индекса, упитанности и др.

\section{Таблица 1}

Размерно-массовые характеристики черноморской скорпены из разных бухт г. Севастополя в 2017-2019 гг.

\begin{tabular}{|c|c|c|c|c|c|c|}
\hline \multirow{2}{*}{$\begin{array}{c}\text { Возраст, } \\
\text { год }\end{array}$} & \multirow{2}{*}{ пол } & \multicolumn{5}{|c|}{ бухты } \\
\hline & & Балаклавская & Круглая & Стрелецкая & Карантинная & Севастопольская \\
\hline \multicolumn{7}{|c|}{ общая длина (TL, cM) } \\
\hline \multirow{2}{*}{$2-3$} & q & $11,5 \pm 0,68$ & - & $11,7 \pm 0,67$ & $13,5 \pm 0,19$ & $14,2 \pm 0,23$ \\
\hline & $0^{\pi}$ & $12,6 \pm 0,99$ & $13,1 \pm 0,57$ & $11,3 \pm 0,5^{*}$ & $13,1 \pm 0,26$ & $13,4 \pm 0,29 *$ \\
\hline \multirow{2}{*}{$4-5$} & 우 & $15,9 \pm 0,35$ & $16,9 \pm 2,45$ & $16,06 \pm 0,5$ & $15,3 \pm 0,33$ & $15,1 \pm 0,18$ \\
\hline & $\sigma^{7}$ & $15,8 \pm 0,8$ & $14,2 \pm 0,5$ & $13,6 \pm 0,4$ & $14,3 \pm 0,29$ & $13,7 \pm 0,16$ \\
\hline \multicolumn{7}{|c|}{ стандартная длина (SL, cм) } \\
\hline \multirow{2}{*}{$2-3$} & 우 & $9,0 \pm 0,6$ & - & $9,4 \pm 0,65$ & $10,6 \pm 0,15$ & $11,2 \pm 0,19$ \\
\hline & $\sigma^{7}$ & $9,9 \pm 0,79$ & $10,3 \pm 0,49$ & $8,8 \pm 0,4$ & $10,3 \pm 0,22$ & $10,5 \pm 0,23$ \\
\hline \multirow{2}{*}{$4-5$} & 우 & $12,7 \pm 0,29$ & $13,5 \pm 1,08$ & $12,5 \pm 0,41$ & $12,0 \pm 0,27$ & $11,9 \pm 0,15$ \\
\hline & $0^{x}$ & $11,7 \pm 0,54$ & $11,2 \pm 0,42$ & $10,6 \pm 0,33$ & $11,3 \pm 0,24$ & $10,7 \pm 0,13$ \\
\hline \multicolumn{7}{|c|}{ мacca, $\Gamma$} \\
\hline \multirow{2}{*}{$2-3$} & q & $30,7 \pm 8,43$ & - & $43,2 \pm 8,81$ & $49,2 \pm 2,57$ & $57,3 \pm 3,1$ \\
\hline & $0^{x}$ & $45,4 \pm 16,4$ & $39,9 \pm 5,14$ & $32,3 \pm 4,65$ & $44,8 \pm 2,9$ & $48,5 \pm 3,99$ \\
\hline \multirow{2}{*}{$4-5$} & 우 & $87,05 \pm 7,1$ & $99,2 \pm 25,5$ & $95,6 \pm 9,79$ & $77,4 \pm 6,43$ & $72,5 \pm 2,7$ \\
\hline & $0^{x}$ & $68,4 \pm 9,07$ & $53,18 \pm 8,76$ & $56,0 \pm 5,31$ & $54,04 \pm 3,34$ & $49,6 \pm 1,83$ \\
\hline
\end{tabular}

Показано, что у самок скорпены почти всех возрастных групп индекс жабр достигает максимальных значений у особей из бухт Круглой и Стрелецкой (рис. 2). У самцов этот параметр не имеет зависимости от возраста, а также акваторий отлова. Достоверных отличий между величинами ИЖ одновозрастных экземпляров из разных бухт не установлено.

В предыдущие годы (2017-2018 гг.) на основании анализа индекса жабр были выявлены как наиболее загрязнённые бухты Севастопольская и Стрелецкая, в которых индекс и объём жабр скорпены были незначительно выше, чем в других акваториях [Кузьминова, Зозуль, 2019]. Вместе с тем, как было отмечено ранее, достоверных отличий в ИЖ морского ерша из разных бухт мы не обнаружили, что, вероятно, свидетельствует о сходстве экологических условий обитания. Литературные данные о состоянии разных представителей ихтиофауны: полосатой крупночешуйной кефали Liza macrolepis (Smith, 1846), сома ариус Arius gagora (Hamilton, 1822), мохарры Gerres oyena (Forsskål, 1775) и красноухого летрина Lethrinus lentjan (Lacepède, 1802) демонстрируют факт того, что в загрязнённых водоемах данный индекс достоверно выше, чем в чистых акваториях [Аль-Бурай, 2013; Романова, Спирина, 2010; Спирина, 2011; Шайдуллина, 2009]. 

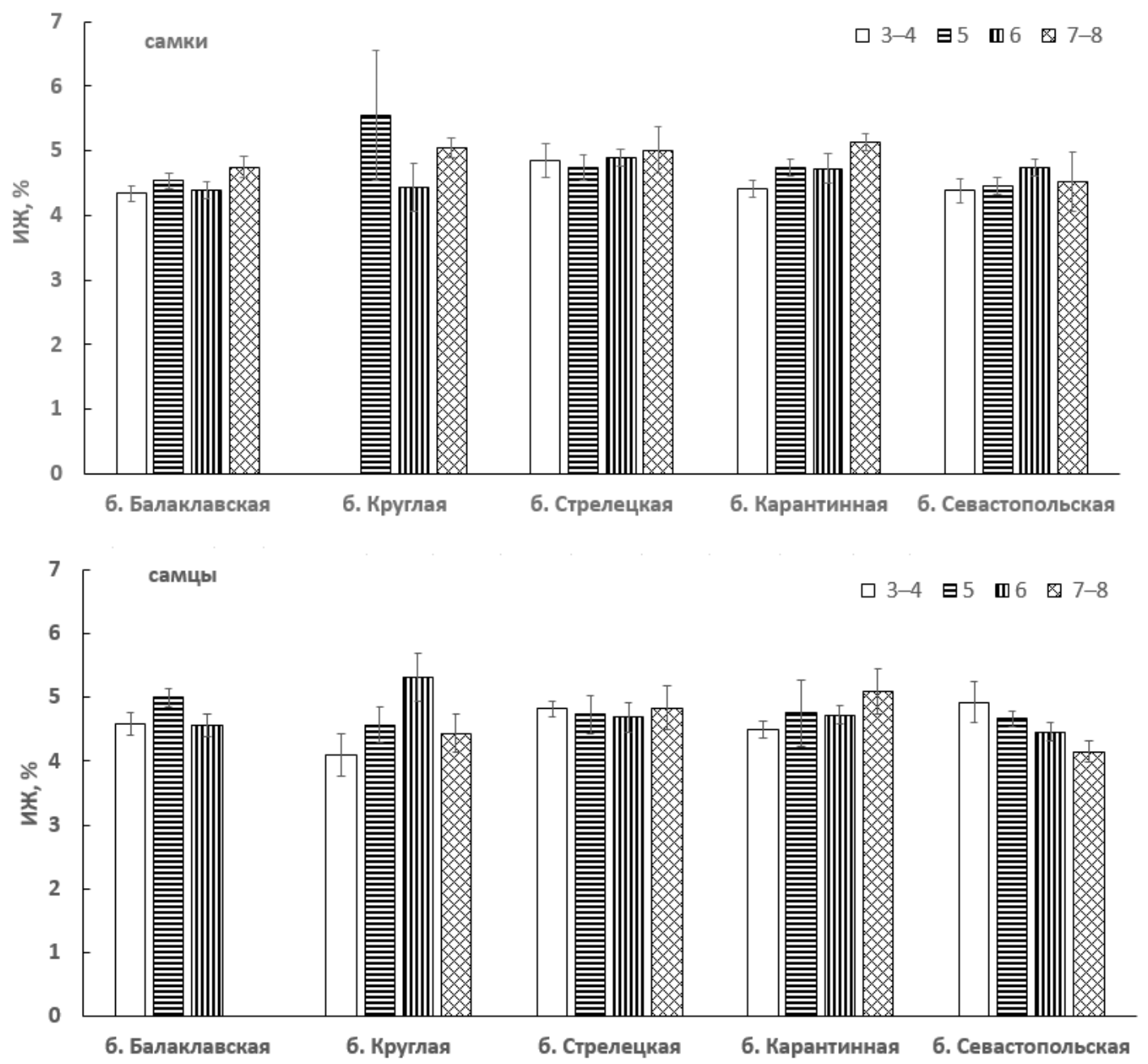

Рис. 2. Индекс жабр черноморской скорпены из бухт г. Севастополя в 2017-2019 гг.

Индекс печени имеет наивысшие значения у самок в возрасте трёх - шести лет в бухтах Балаклавской и Стрелецкой. У самок в возрасте семи - восьми лет этот индекс выше у представителей из бухт Севастопольской и Балаклавской (рис. 3). У самцов разного возраста ИП имеет максимальные величины у рыб из бухты Стрелецкой. Достоверными при этом оказались отличия в ИП самок возрастом пяти и семи - восьми лет из бухт Круглой и Балаклавской, трёх — четырёх и шести лет - из бухт Севастопольской и Балаклавской и семи — восьми лет — для рыб из бухт Севастопольской и Круглой, Карантинной и Стрелецкой, а также Карантинной и Севастопольской. ИП самок в возрасте трёх - четырёх лет из бухт Карантинной и Стрелецкой достоверно ниже такового у самок из бухты Балаклавской. У самцов в возрасте шести лет из акватории Карантинной бухты величина ИП достоверно отличается от аналогичного показателя у самцов того же возраста из акваторий бухт Севастопольской и Стрелецкой.

Тот факт, что масса печени морского ерша увеличивается при влиянии на него комплексного загрязнения, подтверждается известными данными об аналогичном эффекте и у других представителей ихтиофауны, в том числе черноморских видов рыб [Герман и др., 2002; Кузьминова и др., 2016; Силкин и др., 2019; Al-Ghais, 2013]. Следует при этом отметить, что такая реакция - повышение величины ИП — является адаптивной и возможна лишь при умеренном уровне загрязнения акваторий [Аль-Бурай, 2013; Authman, 2011]. 

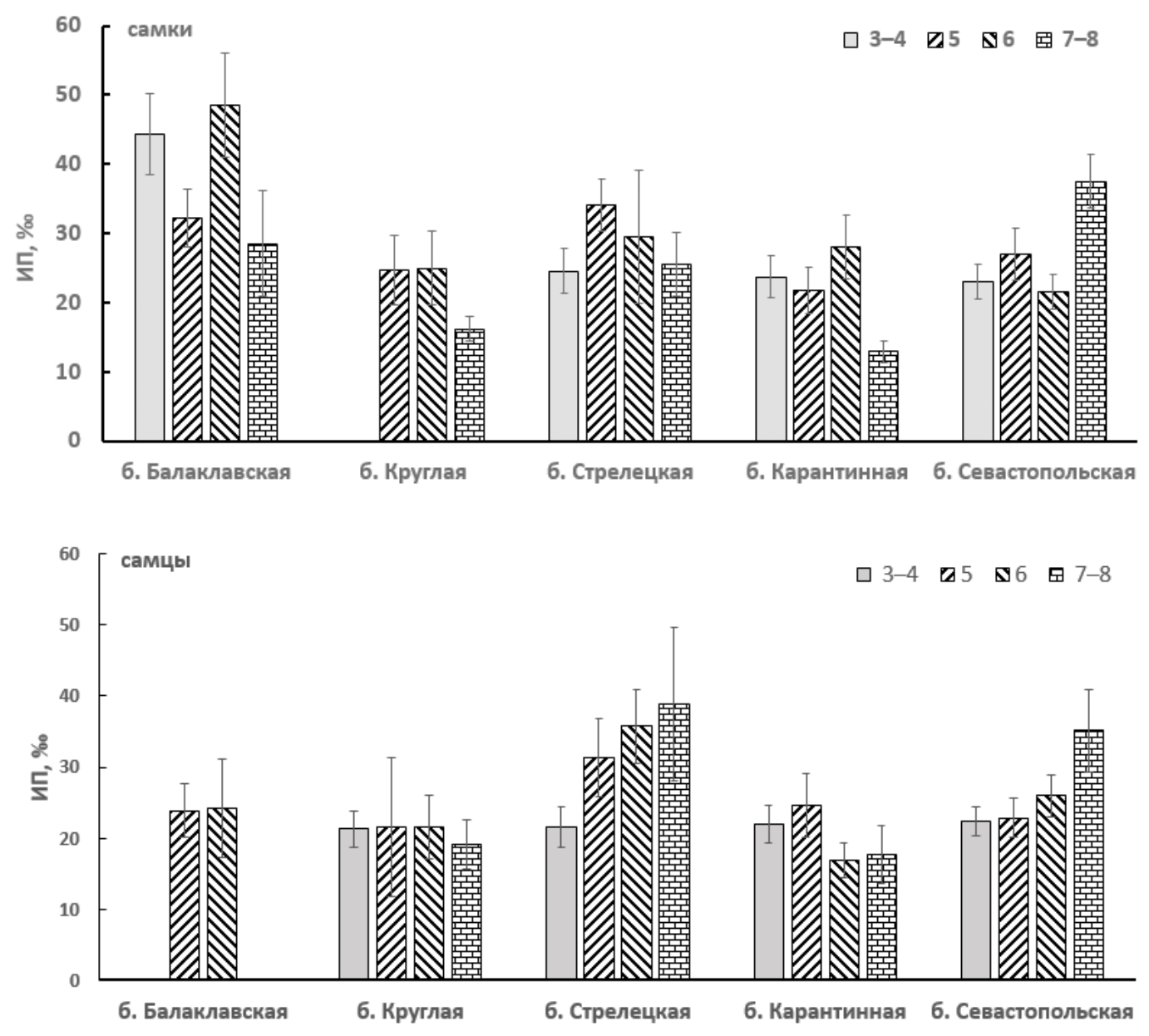

Рис. 3. Индекс печени черноморской скорпены из бухт г. Севастополя в 2017-2019 гг.

Несмотря на сходство величин популяционных и морфофизиологических параметров, на основании наших данных можно сделать вывод, что ёрш из Стрелецкой и Севастопольской бухт находится в худшем функциональном состоянии. Это выражается в повышенных величинах ИП и более низких величинах размера и массы у особей средней возрастной группы. Взрослые экземпляры скорпены из бухты Балаклавской имеют более высокие значения размера и массы рыб, а также печени, что, скорее всего, указывает на благоприятные кормовые условия в этой акватории.

Это согласуется с данными о том, что концентрация нефтяных углеводородов в донных осадках Севастопольской и Стрелецкой бухт достаточно высокая, результатом чего стало накопление данного загрязнителя в населяющих донные отложения бентосных двустворчатых моллюсках [Миронов и др., 2018]. Интересно, что литературные данные о загрязнении Балаклавской бухты свидетельствуют о том, что видовое разнообразие биоты не отличается насыщенностью, а виды макрозообентоса, присутствующие в этой акватории, устойчивы к загрязнению и дефициту кислорода; уровень органического вещества и нефтяных углеводородов в донных отложениях высокий, как и содержание Fe (II) в поровых водах бухты, что было сопоставимо с его концентрацией в наиболее нагруженных акваториях Севастопольской и Стрелецкой бухт [Орехова, Овсяный, Тихонова, 2019; Тихонова, Котельянец, Гуров, 2019]. Несмотря на тенденцию восстановления акватории по сравнению с 90-ми годами прошлого столетия, Балаклавская бухта всё ещё относится к зоне экологического риска. Однако пятнистость 
распределения зообентоса, специфические, благоприятствующие самоочищению гидродинамические процессы и близость расположения донного ставника к открытой части бухты, возможно, играют не последнюю роль в формировании условий обитания скорпены. На наш взгляд, именно кормовая база является ключевым фактором, определяющим указанные отличия в популяционных параметрах рыб. Так как основными объектами питания черноморского ерша являются ставрида и султанка [Кузьминова, Чеснокова, Архипова, 2017], регулярно заходящие в Балаклавскую бухту, то количественно-видовой состав зообентоса, а также экологическое состояние акватории являются для скорпены второстепенными факторами.

Это подтверждается нашей предыдущей работой: в то время как в Севастопольской бухте основная доля рациона скорпены приходилась на рыб, декапод и амфипод, в Стрелецкой и Балаклавской — исключительно на рыб и, по причине большей калорийности таких пищевых объектов, это отразилось на величинах упитанности, индекса печени [Тимофеев и др., 2020]. И в настоящее время, как видно на рис. 4, эта тенденция сохраняется.

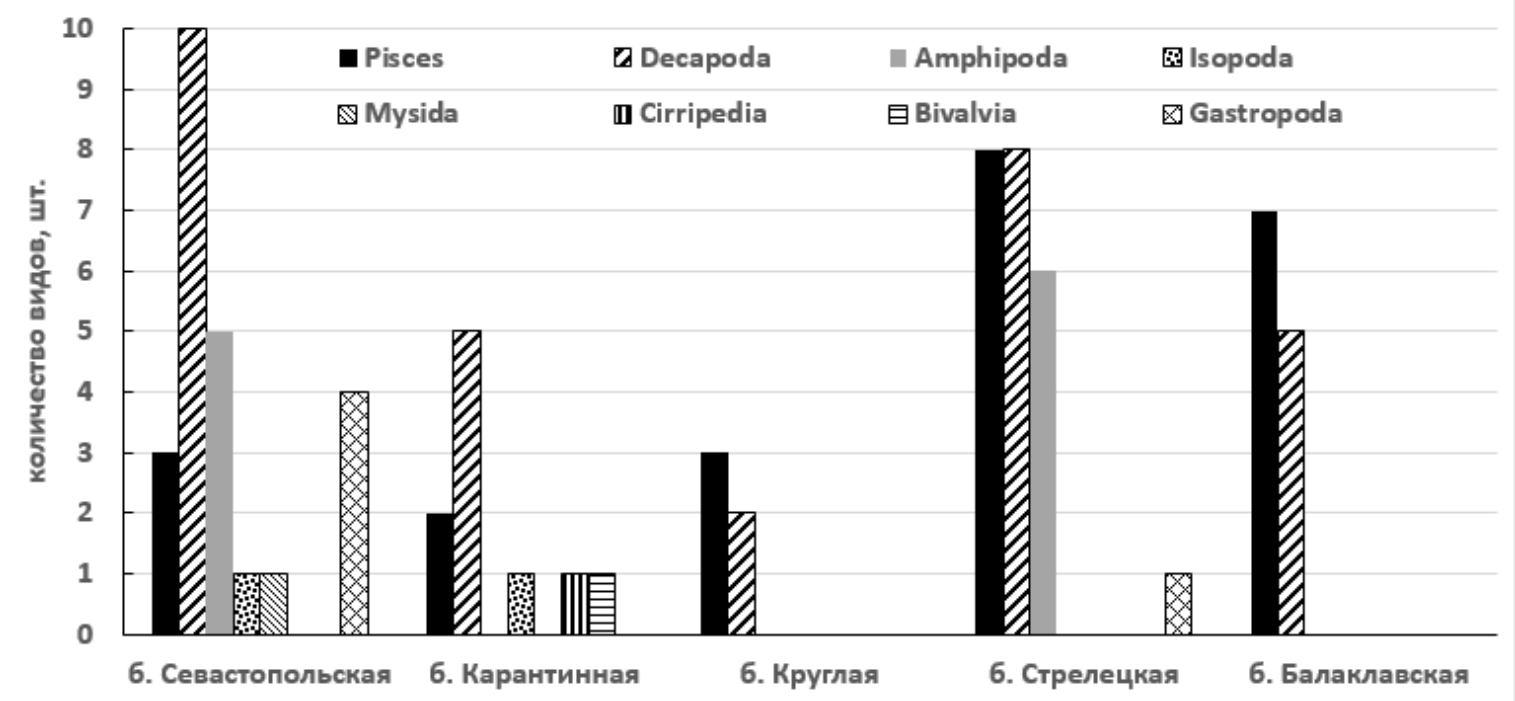

Рис. 4. Количество видов разных групп пищевых объектов черноморской скорпены из бухт г. Севастополя в 2017-2019 гг.

В пользу данного предположения можно представить наши данные биохимического анализа печени ерша, проведённые ранее для рыб из нескольких акваторий, отличающихся экологическими условиями.

На основании предварительных расчётов было установлено, что концентрация холестерина, $\beta$-липопротеидов и активность липазы в печени не зависели от возраста и пола скорпены. Этот факт согласуется с другими исследованиями: в крови тиляпии Oreochromis aureus (Steindachner, 1864) уровень холестерина и липидов в печени не связаны с возрастом/размером особей [Miliou, Papoutsoglou, 1997], а активность липазы в печени, кишечнике, пилорических придатках и желудке, красных мышцах роху Labeo rohita (Hamilton, 1822), индийской скумбрии Rastrelliger kanagurta (Cuvier, 1816), кефали Liza subviridis (Valenciennes, 1836), жирной индийской сардины Sardinella longiceps (Valenciennes, 1847) также не имела достоверных отличий между группами рыб разного размера / массы [Nayak et al., 2003]. Установлено, что все изученные биохимические параметры в бухте Балаклавской были максимальными (табл. 2). Достоверные отличия уровня холестерина получены для рыб из бухт Карантинной и Балаклавской, а также Карантинной и Севастопольской, а концентрации липазы - у особей из бухт Севастопольской и Балаклавской. 
Таблица 2

Биохимические параметры печени черноморской скорпены, обитающей в разных бухтах (в пересчёте на г белка)

\begin{tabular}{|l|c|c|c|}
\hline \multirow{2}{*}{\multicolumn{1}{|c|}{ Параметр }} & \multicolumn{3}{|c|}{ район (бухта) } \\
\cline { 2 - 4 } & Севастопольская & Карантинная & Балаклавская \\
\hline холестерин, ммоль/л & $\mathbf{0 , 0 4} \pm \mathbf{0 , 0 0 0 5}$ & $\mathbf{0 , 0 2 3} \pm \mathbf{0 , 0 0 3 *}$ & $0,042 \pm 0,006$ \\
\hline$\beta$-липопротеиды, опт. ед. & $0,301 \pm 0,045$ & $0,569 \pm 0,241$ & $0,748 \pm 0,385$ \\
\hline липаза, мл $\mathrm{NaOH} / г$ белка/ч & $\mathbf{0 , 1 5 6} \pm \mathbf{0 , 0 4}$ & $0,429 \pm 0,234$ & $\mathbf{1 , 6 0 9} \pm \mathbf{0 , 5 1}$ \\
\hline
\end{tabular}

Примечание: жирным шрифтом выделены достоверно различающиеся значения,

* _ достоверные различия с параметрами рыб из б. Балаклавской

Известно, что исследованные биохимические маркеры отражают физиологическое состояние рыб, характеризуя метаболизм жирных кислот в их организме [Akhavan et al., 2016; Elham A. Wasset, Olfat M. Wahbi, Shaymaa H. Shalaby, 2011]. Имеются сведения, что влияние As, $\mathrm{Hg}, \mathrm{Ni}, \mathrm{Zn}, \mathrm{Cd}, \mathrm{Cu}, \mathrm{Co}, \mathrm{Cr}$ может неоднозначно изменять активность пищеварительных ферментов, в частности липазы, у пресноводных рыб в связи с разным временем воздействия токсикантов и их концентраций [Al-Attar, 2007; Al-Ghanem, 2011; Firat, Kargin, 2010; Sarita, Jain, 2009; Sornaraj, Thanalashmi, Baskaran, 1995; Tang et al., 2013]. Аналогичный эффект экспозиции был установлен и при воздействии хлорорганического пестицида паррисульфана и инсектицида лямбда-цигалотрина на уровень липазы в мышцах и печени сомика полосатого Mystus vittatus (Bloch, 1794) и змееголова пятнистого Channa punctatus (Bloch, 1793) [Sornaraj et al., 2007; Saxena, Sirohi, 2007]. Бедный пищевой рацион, как, впрочем, и загрязнение (в случае если это долговременные факторы), как известно, вызывают снижение уровня глюкозы в плазме крови, холестерина, белка и триглицеридов, а также концентрации белка, гликогена в печени и белых мышцах рыб [Bani, Vayghan, 2011; Pérez-Jiménez et al., 2012; Shreni, 1979; Zutshi, Prasad, Nagaraja, 2010]. В бухтах Матюшенко и Александровской (Большая Севастопольская бухта), по-видимому, это и стало причиной более низких значений холестерина, липопротеинов низкой плотности и активности липазы в печени ерша (табл. 2). Следует указать, что в экспериментальных условиях, при кратковременных токсических нагрузках на рыб, другие исследователи наблюдали противоположный эффект [Hamed, Osman, 2017]. Для бухты Балаклавской повышенные величины изученных биохимических маркеров объясняются отличным от других акваторий рационом скорпены [Papoutsoglou, Papaparaskeva-Papoutsoglou, 1979].

\section{Выводы}

1. Наибольшие величины размера и массы имеют молодые экземпляры морского ерша из бухт Карантинной и Севастопольской, а особи среднего возрастного класса — из бухт Балаклавской, Круглой и Стрелецкой.

2. Увеличение индекса печени скорпены из бухт Стрелецкой и Балаклавской имеет разные причины: в первом случае это результат адаптивного процесса в ответ на высокий уровень загрязнения бухт, что подтверждается и наибольшими величинами индекса жабр, а во втором результат преобладания в пищевом рационе Scorpaena porcus рыб по сравнению с другими акваториями, что согласуется с биохимическими данными жирового обмена.

Благодарности. Авторы выражают благодарность коллегам, проводившим исследования видового состава пищевого спектра скорпены, а также давшим ценные рекомендации при написании статьи, - научному сотруднику, кандидату биологических наук Тимофееву В. А. и младшему научному сотруднику отдела экологии бентоса Бондаренко Л. В. 


\section{Список литературы}

1. Аль-Бурай А. М. Морфофизиологические реакции рыб Красного моря как индикаторы экологического состояния среды : автореф. дис. ... канд. биол. наук : 03.02.08. - Астрахань, 2013. $-24 \mathrm{c}$.

2. Вдодович И. В. Питание личинок черноморских бычков в прибрежной акватории Севастополя в летний период по материалам 2003-2009 гг. // Экология моря / НАН Украины, Ин-т биологии юж. морей. - Севастополь, 2008. - Вып. 76. - С. 40-44.

3. Герман А. В., Чуйко Г. М., Флеров Б. А., Тиллитт Д., Зайчек Д. Морфометрические и физиолого-биохимические показатели рыб как биоиндикаторы загрязнения водоёмов // Современные проблемы водной токсикологии : всерос. конф. с участием специалистов ближ. и дал. зарубежья, 19-21 нояб. 2002 г. : тез. докл. / Ин-т биологии внутр. вод им. И. Д. Папанина РАН [и др.]. - Борок : [б. и.], 2002. - С. 21-32.

4. Климова Т. Н. Ихтиопланктон в прибрежной акватории Юго-Западного Крыма в 2002-2008 гг. // Морской экологический журнал. - 2010. - Т. 9, № 1. - С. 39-52.

5. Котельянеи, Е. А., Гуров К. И., Тихонова Е. А., Кондратьев С. И. Загрязняющие вещества в донных отложениях Балаклавской бухты (Чёрное море) // Морской гидрофизический журнал. -2019. - Т. 35, № 5. - С. 469-480. - https://doi.org/10.22449/0233-7584-2019-5-469-480

6. Кузьминова Н. С., Зозуль А. Ю. Морфофизиологический анализ жабр черноморских рыб для диагностики состояния прибрежной ихтиофауны // Инновационные подходы в решении современных проблем рационального использования природных ресурсов и охраны окружающей среды : междунар. науч.-техн. конф. (Алушта, 3-7 июня 2019 г.) : сб. докл. / М-во образования и науки РФ [и др.] ; ред. кол.: Н. В. Беседина. - Белгород : Белгород. гос. технол. ун-т им. В. Г. Шухова, 2019. - Ч. 1. - С. 46-53.

7. Кузьминова Н. С., Мурзин Ю. Л., Самотой Ю. В. Популяционные, морфофизиологические и морфометрические отличия черноморской ставриды из прибрежной зоны Севастополя и Балаклавы // Учёные записки Крымского федерального университета им. В. И. Вернадского. Биология. Химия. - 2018. - Т. 4 (70), № 4. - С. 97-107.

8. Кузьминова Н. С., Овен Л. С., Салехова Л. П., Шевченко Н. Ф., Самотой Ю. В. Долговременные изменения популяционных и морфофизиологических параметров некоторых видов черноморских рыб из прибрежной зоны Севастополя и Крыма // Экотоксикологические исследования прибрежной черноморской ихтиофауны в районе Севастополя / Ин-т мор. биол. исслед. им. А. О. Ковалевского РАН, Рос. фонд фундам. исслед. ; отв. ред. И. И. Руднева. Москва : Геос, 2016. - Гл. 2. - С. 31-124.

9. Кузьминова Н. С., Чеснокова И. И., Архипова С. В. Современные сведения о питании и пищеварении черноморской скорпены (Scorpaena porcus L.) // Экосистемы. - 2017. Вып. 10 (40). - С. 52-63.

10. Кучеренко Н. Е., Васильев А. Н. Липиды. - Киев : Вища шк., 1985. - 247 с.

11. Методические указания к лабораторно-практическим работам по дисциплине «химия пищевая» (часть 2) и к лабораторно-практическим работам по дисциплине «физико-химические и статистические методы оценки качества пищевых продуктов» для студентов, обучающихся по специальности 110305.65 «технология производства и переработки сельскохозяйственной продукции» / Кубан. гос. аграр. ун-т. - Краснодар : КГАУ, 2011. - 38 с.

12. Миронов О. Г., Миронов О. А., Муравьёва И. П., Тихонова Е. А., Осадчая Т. С., Волков Н. Г. Нефтяные углеводороды в гидробионтах // Санитарно-биологические исследования прибрежных акваторий Юго-Западного Крыма в начале XXI века / Ин-т мор. биол. исслед. им. А. О. Ковалевского РАН ; отв. ред.: О. Г. Миронов, С. В. Алёмов. - Симферополь : Ариал, 2018. - [Гл.] 2. - С. 22-49. 
13. Овен Л. С., Руднева И. И., Шевченко Н. Ф. Ответные реакции морского ерша Scorpaena porcus (Scorpaenidae) на антропогенное воздействие // Вопросы ихтиологии. - 2000. T. 40, № 1. - C. 75-78.

14. Орехова Н. А., Овсяный Е. И., Тихонова Е. А. Органическое вещество и окислительновосстановительные условия в донных отложениях Балаклавской бухты // Учёные записки Крымского федерального университета имени В. И. Вернадского. Биология. Химия. - 2019. - Т. 5 (71), № 3. - С. 49-64.

15. Правдин И. Ф. Руководство по изучению рыб (преимущественно пресноводных) / под ред. П. А. Дрягина, В. В. Покровского. - 4-е изд., перераб. и доп. - Москва : Пищ. пром-сть, 1966. - 376 с.

16. Пример расчета критерия U Манна - Уитни // Математическая статистика для психологов : [сайт]. - [20??]. - URL: https://statpsy.ru/mana-uitni/primer-mana-uitni/ (дата обращения: 05.04.2021).

17. Пример расчета t-критерия Стьюдента для независимых выборок // Математическая статистика для психологов : [сайт]. - [20??]. - URL: https://statpsy.ru/t-student/primer-t-test-ind/ (дата обращения: 05.04.2021).

18. Ревков Н. К. Макрозообентос украинского шельфа Чёрного моря // Промысловые биоресурсы Чёрного и Азовского морей / НАН Украины, Ин-т биологии юж. морей им. А. О. Ковалевского ; ред.: В. Н. Еремеев [и др.]. - Севастополь : ЭКОСИ - Гидрофизика, 2011. - [Парагр.] 5.1. - С. 140-162.

19. Романова Е. М., Спирина Е. В. Морфофизиологические адаптации Carassius auratus gibelio Bloch. в биоиндикации состояния пресноводных экосистем // Вестник Ульяновской государственной сельскохозяйственной академии. - 2010. - № 2 (12). - С. 31-36.

20. Руднева И. И. Ответные реакции морских животных на антропогенное загрязнение Чёрного моря : дис. ... д-ра биол. наук : 03.00.29. - Севастополь, 2000. - 329 с.

21. Санитарно-биологические исследования прибрежных акваторий Юго-Западного Крыма в начале XXI века / Ин-т мор. биол. исслед. им. А. О. Ковалевского РАН ; отв. ред.: О. Г. Миронов, С. В. Алёмов. - Симферополь : Ариал, 2018. - 270 с.

22. Силкин Ю. А., Василеи В. Е., Силкина Е. Н., Петрова Т. Н., Черняева В. Н. Морфофизиологические характеристики черноморского саргана (Belone belone euxini Günter, 1866) в посленерестовом периоде у берегов Юго-Восточного Крыма // Экосистемы. - 2019. Вып. 17 (47). - С. 77-86.

23. Спирина E. В. Морфофизиологический гомеостаз Carassius auratus gibelio Bloch // Проблемы региональной экологии. - 2011. - № 1. - С. 57-62.

24. Тимофбеев В. А., Кузьминова Н. С., Бондаренко Л. В., Куликов Г. В. Современные сведения о пищевом спектре черноморской скорпены Scorpaena porcus Linnaeus, 1758 // Вестник Института биологии Коми НЦ УрО РАН. - 2020. - № 1 (212). - С. 2-12. https://doi.org/10.31140/j.vestnikib.2020.1(212).1

25. Тихонова E. А., Котельянеи, E. А., Гуров К. И. Содержание органических веществ и тяжёлых металлов в донных отложениях Балаклавской бухты (Чёрное море) // Экологическая безопасность прибрежной и шельфовой зон моря. - 2019. - № 3. - С. 82-89. https://doi.org/10.22449/2413-5577-2019-3-82-89

26. Цитофізіологія і біохімія травлення : практикум : навч. посіб. / Т. В. Берегова [та ін.] ; за ред. Л. І. Остапенко, В. К. Рибальченка. - Київ : Київ. ун-т, 2006. - 271 с.

27. Шайдуллина Ж. М. Сезонная и возрастная динамика морфофизиологических показателей леща реки Урал : автореф. дис. ... канд. биол. наук : 03.00.10. - Астрахань, 2009. - 24 с. 
28. Швари, С. С., Смирнов В. С., Добринский Л. Н. Метод морфофизиологических индикаторов в экологии наземных позвоночных. - Свердловск : [б. и.], 1968. - 387 с. - (Труды Института экологии растений и животных ; вып. 58).

29. Экотоксикологические исследования прибрежной черноморской ихтиофауны в районе Севастополя : монография / Завьялов А. В. [и др.] ; Ин-т мор. биол. исслед. им. А. О. Ковалевского РАН ; Рос. фонд фундам. исслед. - Москва : Геос, 2016. - 358 с.

30. Akhavan S. R., Salati A. P., Falahatkar B., Jalali S. A. H. Changes of vitellogenin and lipase in captive sterlet sturgeon Acipenser ruthenus females during previtellogenesis to early atresia // Fish Physiology and Biochemistry. - 2016. - Vol. 42, iss. 3. - P. 967-978. https://doi.org/10.1007/s10695-015-0189-8

31. Al-Attar A. M. The influences of Nickel exposure on selected physiological parameters and gill structure in the teleost fish, Oreochromis niloticus // Journal of Biological Sciences. - 2007. - Vol. 7 , iss. 1. - P. 77-85.

32. Al-Ghais $S$. $M$. Acetylcholinesterase, glutathione and hepatosomatic index as potential biomarkers of sewage pollution and depuration in fish // Marine Pollution Bulletin. - 2013. - Vol. 74, iss. 1. P. 183-186.

33. Al-Ghanem Kh. A. Effect of cobalt-supplemented diets on bioaccumulation, digestive enzyme activities and growth of Cyprinus carpio // Toxicological and Environmental Chemistry. - 2011. Vol. 93, iss. 5. - P. 985-995. - https://doi.org/10.1080/02772248.2011.568088

34. Authman M. M. N. Environmental and experimental studies of aluminium toxicity on the liver of Oreochromis niloticus (Linnaeus, 1758) fish // Life Science Journal. - 2011. - Vol. 8, no. 4. P. 764-776. - https://doi.org/10.7537/marslsj080411.100

35. Bani A., Vayghan A. H. Temporal variations in haematological and biochemical indices of the Caspian kutum, Rutilus frisii kutum // Ichthyological Research. - 2011. - Vol. 58, iss. 2. P. 126-133. - https://doi.org/10.1007/s10228-010-0199-6

36. Elham A. Wasset, Olfat M. Wahbi, Shaymaa H. Shalaby. Effects of dietary vegetable oils on liver and gonad fatty acid metabolism and gonad maturation in gilthead seabream (Sparus aurata) males and females // Aquaculture International. - 2011. - Vol. 20, iss. 2. - P. 255-281. https://doi.org/10.1007/s10499-011-9454-8

37. Firat $\ddot{O}$., Kargin $F$. Biochemical alterations induced by $\mathrm{Zn}$ and $\mathrm{Cd}$ individually or in combination in the serum of Oreochromis niloticus // Fish Physiology and Biochemistry. - 2010. - Vol. 36, iss. 3. P. 647-653. - https://doi.org/10.1007/s10695-009-9337-3

38. Hamed H. S., Osman A. G. M. Modulatory effect of lycopene against carbofuran toxicity in African catfish, Clarias gariepinus // Fish Physiology and Biochemistry. - 2017. - Vol. 43, iss. 6. P. 1721-1731. - https://doi.org/10.1007/s10695-017-0404-X

39. Miliou H., Papoutsoglou S. E. Blue tilapia Oreochromis aureus (Steindachner) carcass composition and haematology in relation to the female parent size under recirculated water conditions // Aquaculture Research. - 1997. - Vol. 28, iss. 8. - P. 629-634. - https://doi.org/10.1046/j.13652109.1997.00905.x

40. Nayak J., Nair P. G. V., Ammu K., Mathew S. Lipase activity in different tissues of four species of fish: rohu (Labeo rohita Hamilton), oil sardine (Sardinella longiceps Linnaeus), mullet (Liza subviridis Valenciennes) and Indian mackerel (Rastrelliger kanagurta Cuvier) // Journal of the Science of Food and Agriculture. - 2003. - Vol. 83, iss. 11. - P. 1139-1142. https://doi.org/10.1002/jsfa.1515

41. Papoutsoglou S. E., Papaparaskeva-Papoutsoglou E. G. Further observations on haematological and liver characteristics of farmed rainbow trout (Salmo gairdneri, R.) // Thalassographica. - 1979. Vol. 3, no. 1. - P. 21-34. 
42. Pérez-Jiménez A., Cardenete G., Hidalgo M. C., García-Alcázar A., Abellán E., Morales A. E. Metabolic adjustments of Dentex dentex to prolonged starvation and refeeding // Fish Physiology and Biochemistry. - 2012. - Vol. 38, iss. 4. - P. 1145-1157. https://doi.org/10.1007/s10695-011-9600-2

43. Sarita, Jain K. L. Chronic effects of heavy metals on the activity of some digestive and metabolic enzymes in Cyprinus carpio // Annals of Biology. - 2009. - Vol. 25, iss. 1. - P. 63-67.

44. Saxena K. K., Sirohi $V$. Effect of $\lambda$-cyhalothrin on the activities of trypsin and lipase in fresh water fish Channa punctatus // Journal of Fisheries and Aquatic Science. - 2007. - Vol. 2, iss. 2. P. 168-172. - https://doi.org/10.3923/jfas.2007.168.172

45. Shreni K. D. Influence of starvation on the brain and liver chelesterol levels of the cat-fish, Heteropneustes fossilis (Bloch) // Proceedings: Animal Science. - 1979. - Vol. 88, iss. 3. P. 205-208. - https://doi.org/10.1007/BF03179095

46. Sornaraj R., Singh A., Pushparaj A., Jaisheeba A. A. Alterations in lipid metabolism in the fish mystus vittatus exposed to organochlorine and organophosphate pesticides // Journal of Ecotoxicology \& Environmental Monitoring. - 2007. - Vol. 17, iss. 6. - P. 557-563.

47. Sornaraj R., Thanalashmi S., Baskaran P. Influence of heavy metals on biochemical responses of the freshwater air-breathing fish Channa punctatus (Bloch) // Journal of Ecotoxicology \& Environmental Monitoring. - 1995. - Vol. 5, iss. 1. - P. 19-27.

48. Tang Q. Q., Feng L., Jiang W. D., Liu Y., Jiang J., Li S. H., Kuang S. Y., Tang L., Zhou $X$. Q. Effects of dietary copper on growth, digestive, and brush border enzyme activities and antioxidant defense of hepatopancreas and intestine for young grass carp (Ctenopharyngodon idella) // Biological Trace Element Research. - 2013. - Vol. 155, iss. 3. - P. 370-380. https://doi.org/10.1007/s12011-013-9785-6

49. Zutshi B., Prasad S. G. R., Nagaraja R. Alteration in hematology of Labeo rohita under stress of pollution from Lakes of Bangalore, Karnataka, India // Environmental Monitoring and Assessment. - 2010. - Vol. 168, iss. 1. - P. 11-19. https://doi.org/10.1007/s10661-009-1087-2

\title{
STATE OF BIOMONITORIAL SPECIES, BLACK SEA SCORPION FISH (SCORPAENA PORCUS LINNAEUS, 1758), IN COASTAL AREA OF SEVASTOPOL
}

Kuzminova N. S. ${ }^{1,2}$, Zozul A. Yu. ${ }^{2}$, Grebnev V. I. ${ }^{3}$, Vasilyeva A. A. ${ }^{3}$, Tsygylyk E. I. ${ }^{3}$

${ }^{1}$ A. O. Kovalevsky Institute of Biology of the Southern Seas of RAS, Sevastopol, Russian Federation,

${ }^{2}$ Sevastopol Environmentally-Educational Student Centre, Sevastopol, Russian Federation,

${ }^{3}$ Sevastopol State University, Sevastopol, Russian Federation,

e-mail:kunast@rambler.ru

\begin{abstract}
The paper presents data on the size-mass, morphophysiological characteristics of the Black Sea scorpion fish Scorpaena porcus from five bays of Sevastopol in the period 2017-2019. It was found that young specimens are larger in the bays of Karantinnaya (TL $13.5 \pm 0.19 \mathrm{~cm}$ ) and Sevastopolskaya (TL $14.2 \pm 0.23 \mathrm{~cm}$ ), and individuals of the middle age class - in Balaklavskaya (TL $15.9 \pm 0,35 \mathrm{~cm}$ ), Kruglaya (TL $16.9 \pm 2.45 \mathrm{~cm}$ ) and Streletskaya (TL $16.06 \pm 0.5 \mathrm{~cm}$ ). In response to the higher level of complex pollution of Streletskaya bay, males of different ages had an increased hepato-somatic index (HSI). The same adaptive effect — the gill index has maximum values - was observed for individuals from Kruglaya and Streletskaya bays. HSI of females from 3 to 8 years old is increased for scorpion fish from Balaklavskaya bay, but in this case it is a result of a higher-calorie diet (predominance of fish), which is confirmed both by the analysis of the food spectrum of the Scorpaena porcus and by the values of some biochemical parameters of fat metabolism (levels of cholesterol, $\beta$-lipoproteine and lipase activity). So, in 2017-2019 the scorpion fish was in a more favorable physiological state in the Balaklavskaya and Karantinnaya bays, and to a lesser extent — in the water area of the Streletskaya bay.
\end{abstract}

Keywords: scorpion fish, bays of Sevastopol, pollution. 


\section{Сведения об авторах}

Кузьминова

Наталья

Станиславовна

Зозуль

Алена

Юрьевна

Гребнев

Владислав

Игоревич

Васильева

Анна

Анатольевна

Цыгылык

Елена

Игоревна кандидат биологических наук, старший научный сотрудник, ФГБУН ФИЦ «Институт биологии южных морей имени А. О. Ковалевского РАН», kunast@ rambler.ru

ученица, Севастопольский центр эколого-натуралистического творчества учащейся молодежи

студент 2-го курса, Севастопольский государственный университет

студентка 4-го курса, Севастопольский государственный университет

студентка 4-го курса, Севастопольский государственный университет

Поступила в редакцию 17.10.2020 г.

Принята к публикации 31.03.2021 2. 